\title{
Mission in the new South Africa. Need for a renewed enquiry
}

J J Kritzinger

(University of Pretoria)

\begin{abstract}
Mission in the new South Africa. Need for a renewed enquiry

Mission includes all that the church is called by its Lord to do in continuation of His mission in the world. The church in her mission is interested in the whole of people's lives and needs. The church is also called to mission in the South African context. Do we know this context? Do we understand the challenges of this context? A project of two decades ago on the unfinished task of mission in South Africa brought many relevant insights to the force, but since then the context has changed dramatically. This article touches on some aspects of the new situation, and provides outlines for the launch of a new enquiry.
\end{abstract}

\section{MISSION}

The answer to the question about the missionary task of the church in South Africa today and tomorrow will depend on how one would understand the word "mission" in our title.

Some people define mission simply as the spreading of the good news about the salvific work of Jesus Christ. This is the church's main and central task: to seek the lost, and to gather them into churches 1 . The accomplishment of this task is measureable: have all people heard this good news or not? Missiological discussions in this case centre on the question whether all people (every single individual) should hear the gospel preached in an intelligible way, or whether the task could be seen as completed when every people (panta ta ethne - Math 28:19; 24:14) have heard it in their own language and idiom ${ }^{2}$. These people prefer to use the term "missions" (in the plural), indicating the many cross-cultural outreaches to the "unreached peoples". Mission is the

\footnotetext{
1 This is the basic approach of (amongst others) the Church Growth Movement, initiated by Donald McGavran in the nineteen sixties, which became a strong force in mission circles. For a good overview of the movement, see Rainer 1993.

2 David Bosch wrote a good contribution on this debate (Bosch 1983:218-248; see also Bosch 1991:64). He indicates that neither of these two alternatives is quite correct. The panta ta ethne is (merely) an indication that the work of salvation of Christ is for all, and that all should be invited to the feast. By the way, when has someone really heard the message?
} 
task of evangelising the unreached, "discipling the nations". The church in its mission should not be tempted to give too much attention to other wort hy issues, such as denouncing discrimination, working for justice, battling poverty, or seeking a better life for all, but focus on the main issue of people's eternal bliss ${ }^{3}$. The task of missions resear-chers is first and foremost to identify and study these unreached peoples, and secondly to concentrate on devising strategies to reach them ${ }^{4}$.

On the other hand, others understand mission so broadly as to encompass "any activity of the church which God desires" (McGavran 1972:189)5. The church's mission is to be the church: God's people, Christ's body on earth, living his (Jesus') life. God's mission (the missio Dei) is the starting point. The missio(nes) ecclesiae is the continuation, in a different way, but in God's name, of God's mission. The church is a missionary people. The church finds its identity and purpose in nothing else than her obedience to this calling. Ecclesiology is only a footnote to missiology. The church has only one task: mission 6 . To know what mission is, is to observe God at work in the world throughout history, but also today, especially through the good things his Church is doing, but mission is definitely not restricted to what the church is accomplishing?.

3 McGavran made an interesting differentiation between "church" and "mission": "The church, but not the mission, touches all of life. The mission has its specific sphere of activity - the communication of the gospel..." (1972:10). Whether one should see it in this way, is debatable.

4 Therefore the plethora of organisations doing strategic planning on a local and global level. Towards the end of the millennium the AD 2000 Movement became the umbrella for many of these.

5 McGavran - as can be expected - decried this. He felt that the new emphasis on the missio Dei (God's mission) confused the task of mission: "The plane of missions has been hijacked. It looks like the old plane on its routine flight to Jerusalem, but is really something new - a plane going to Havana" (1972:190).

6 This kind of thinking, which reached its zenith during the nineteen fifties in the meetings of the ecumenical movement (Willingen and Evanston), and the Dutch apostolaatsteologie, struggled to formulate the difference between church and mission, because they are so fundamentally one. The German missiologist Freytag, for example, used the image of the fire and the flames to describe this relation. In the sixties, realising that too much emphasis could be placed on the church (forgetting the Kingdom), the concept of the mission of the Triune God (missio Dei) moved to centre stage.

7 The understanding of "God's mission" changed over time and, interestingly, led to the secularisation of mission: identifying God at work in the world and joining 
I tend towards the second view, but would, on the other hand, like to heed the warning of McGavran and others. Maybe one should be a little more specific about mission. The church is the body of Christ, yes. The church is continuing the mission of God in the world, yes. The church finds her identity in her obedience to God's will and calling, yes. But mission is not everything the church is doing8. Mission is indeed something special. It belongs to the essence of being church, but it is not all there is to church. Mission is the church at work in the world9. Mission takes place where the church meets the world. Sometimes this meeting (or confrontation) takes place when the Word of God is preached in a worship service and the darkness of unfaithfulness is revealed. At other times the "powers in the air" are confronted when unjust systems are denounced and fought. Mission also means reaching out to people still ignorant of the salvific life and death of Jesus Christ. But when the pastor tends his flock, when the liturgy is followed, when the catechist forms the young church members, they are not doing mission, they are preparing people for their mission. The church also worships, the church members serve each other, and they are in fellowship. This is not mission. What we do say (with Newbigin and Gensichen) is that everything the church does has a missionary dimension, even if not everything has a missionary intention ${ }^{10}$. Mission is the church as witness intentionally in contact with the world.

\section{SOUTH AFRICA: MISSION ACCOMPLISHED?}

\subsection{Reached?}

Those who hold the narrower view of mission, who understand mission as essentially the reaching of the unreached, may, with some justification, see South Africa as removed from the list of "mission fields". The

in the endeavours of those (secular) movements who seem to work in the same direction.

8 The late Stephen Neill is often quoted where he warns: "If everything is mission, nothing is mission" (1959:81). Coming from someone advocating a broad view of mission it should be taken seriously.

9 Bosch liked to speak of mission as "the church-crossing-frontiers", or: "Mission is the symbol of the Church moving towards the world" (1980:17). The "world" is here seen as the realm outside the Christian faith community in the first place, but in another way also as the place where faith meets disobedience in every believer's life.

10 I am not quite sure who of these two said it first, but the argument can be read in Gensichen 1971:80-95). 
latest census figures of 1996, as tabled by Prof Jurgens Hendriks (Froise 1999:48) indicate that $74,1 \%$ of the South African population stated their affiliation to a Christian Church. A further $9,4 \%$, however, refused or just declined to state their affiliation (unpublished table of Stats SA). This would mean that the Christian sector of the population stabilised at slightly more than $3 / 4$ of the total, as it was already $77 \%$ in 1980 (Kritzinger 1985). By no stretch of the imagination can sectors of the population really be regarded as unreached, in the sense of not having had any contact with the gospel ${ }^{11}$.

\subsection{Holistic mission}

Extensive research during the nineteen eighties 12 culminated in a book The South African Context for Mission (Kritzinger 1988). This book came to the conclusion that there was still a tremendous unfinished missionary task for the church. This task was indicated under the rubrics of the three dimensions (as defined earlier in that study) of kerygma (evangelising), diakonia (socio-economic service) and koinonia (the building up of the church in fellowship and liturgy).

Not only was an unfinished task of evangelisation indicated (there were people, groups and geographical areas discovered with quite a low percentage of Christian affiliation), but also "re-evangelisation" of groups where the affiliation was high. The degree of nominality was worrying. The seventy five percent affiliation of the government census could easily be cut with a third to reach the nominal figure on the church rolls (some fifty percent). Of these not far from two thirds are not really active members. This may bring the number of "Christians" down to the order of twenty percent of the population! And are all of these really committed ${ }^{13}$ ?

11 This is not the whole story, however. We will return later on to these statistics. Are all these people really "reached" in the sense that the good news was communicated to them in such a way that they could hear and understand it? Were they really afforded an opportunity to respond to the claims of Christ?

12 This research was conducted under the code name The Unfinished Task of Mission in South Africa. A score of researcher-practicians assisted the present author in describing the different geographical areas of our country from the perspective of the unfinished task. Some two dozen booklets were published, as well as articles, and a book (in Afrikaans and in English) summarising the results (Kritzinger 1988). In the Bibliography of that book the different smaller publications are also listed.

13 These figures were suggested by the results of sampling in some areas. It is a difficult and controversial matter, but, even if the specific percentages may not be 
The unfinished socio-economic calling was almost too painful to describe. Maybe this was the area of the research, which had the strongest impact on the missionary church in South Africa. As the then leadership of the church came to a large extent from the relatively well-todo and educated classes, the facts about the poverty and misery of the people living in especially the deep rural areas came as a shock to them. Some of them even questioned the research results! The Matthew 25 story of the judge, the sheep and the goats became very relevant 14 . The report also touched on the political situation - an area that is always of great importance to the church's mission. In the eighties the apartheid structures were strongly in place, but under increasing tension. What was the calling of the church under such circumstances? There were contrasting views.

The fact is that we could also talk of the unfinished church. Four aspects of church life were analysed. Was the South African church really missionary? Was the church responding to the total needs of the situation - as she should, or was she only interested in preserving her own position? A second aspect was that of the qualitative growth of the church. To what extent did the Bible really function in the church? How thorough was the teaching and pastorate of the church? Were the members being enabled to be the salt and leaven in society, the light shining in the dark? Thirdly: the tragic dependency (financial and otherwise) of the mission established churches was maiming their witness in society. They were struggling to survive, with no vision for anything beyond that. What was to be done in this regard? And finally: the tragedy was the lack of real koinonia, unity, in the body of Christ. The South African society of the nineteen eighties was characterised by conflict and divisions. How could the church act decisively in that context if the same divisions and conflicts wracked the different parts of the body apart? The church had to get her act together!

\subsection{Reactions}

The research results had some effect on the church. Some church leaders and churches actively studied the reports and acted on it. Others were also moved by the picture, which emerged from the process, and were challenged to a greater awareness and involvement.

quite correct, the fact of a great degree of nominality in the Christian church of South Africa should be faced as a reality.

14 No one could escape the clear warning to all Christians: you will be judged according to the compassion that you give or not give towards the poor on your doorstep. 
Still others, unfortunately, either didn't take notice or were so busy with their own agendas that nothing changed.

To one sector of the church - those involved with the South African Council of Churches - the description of the socio-political issues was nothing new. They were brought up on the SPRO-CAS 15 and the SPP ${ }^{16}$ reports, and were already pursuing a political agenda. After years of energetic work they felt vindicated when at the beginning of the nineteen nineties a dramatic change of government came about. The long awaited freedom from minority rule dawned, and those churches (and their leaders) could rightly feel that their "mission" was accomplished 17 .

Other churches stepped up their mission involvement on the ground. Some organisations targeted the less reached areas of the country with evangelistic missions ${ }^{18}$. Others started specialised diaconal ministries (examples are the Apostolic Faith Mission and the Dutch Reformed Church family), seeking solutions to the harsh poverty. Intense mobilisation of the church took place. We are in no way claiming that it all happened because of the previous research project, but in some small way we think that it contributed to the new wave of socio-economic involvement.

15 This project produced a number of important reports critical of the apartheid state. The acronym SPRO-CAS stands for "Study Project on Christianity in Apartheid Society". The project was mooted as a follow-up of the successful The Message to the People of South Africa (1968). A total of 11 reports were published between 1970 and 1973 (see Randall 1973).

16 The Surplus People Project (SPP) published 5 volumes of Forced Removals in South Africa in 1983. It studied the many instances of the relocation of people during the apartheid years.

17 As a matter of fact, it soon became clear to these churches that they had to rediscover their "mission" in the new situation. A first tentative proposal was to work in the context of a "Theology of Reconstruction", in contrast to the earlier common "Theology of Liberation". Other emphases - like a focus on poverty also evolved. Maybe the projects proposed here, could serve as a new integrating theme.

18 There is a revival of missionary interest in the churches of the country, spurred on by a number of very active missionary organisations like the South African Action for World Evangelisation (SAAWE), World Thrust, Operation Mobilisation (OM) and the World Mission Centre. Their initiatives, including the series of Love Southern Africa (LSA) and the international GCOWE conferences, made quite a difference. However, these usually focus not so much on South Africa, but on the unreached world in general and especially the so-called "10-40 window" countries. 
Today more local churches are involved in one or other way in missionary projects than ever before. Not all of these churches are as effectively involved at home as they are reaching out to other countries, but they are nevertheless getting out of their shells.

\section{THE NEW SOUTH AFRICA}

During recent discussions in missionary circles the question came up whether it was not necessary to revisit the topic of the Unfinished Task of Mission in South Africa. Is the understanding of the missionary task and context of two decades ago still relevant? Does the older study still faithfully portray the present context?

There are insights of abiding value in that research and its publications. Some things have (fortunately or unfortunately?) not changed so much on the ground. But other aspects of the context have changed so dramatically that we can honestly speak of a "new" South Africa.

\subsection{Aspects of the New}

For one, the political changes were radical. A totally different dispensation came into being. A new ruling class, with a totally different ideology and a new style, governs according to a new set of rules (constitution) ${ }^{19}$. The political environment changed from an embattled and insular one into one riding the international wave of globalisation and human rights 20 . There are new players in national, provincial and local governments. The flow is consciously in a new direction. The "homelands" don't exist any more. New provinces took the place of the previous structures 21 .

19 It is not necessary to say anything more about "the South African miracle". It made headlines all over the world. A political organisation, banned for almost three decades, with its most famous leader in custody for 27 years, was unbanned, and four years later, after an intensive process of negotiations and elections, formed a government winning almost two-thirds of the votes. The two main players - former foes - received the Nobel Peace Prize together.

20 They say that the South African passport, previously shunned by most countries, now offers entrance into more countries than that of the USA.

21 A great deal of the energy during the earlier research was spent on focusing on the poorest of the poor areas - the periphery of the periphery - namely the nine homelands. The problems of these areas still exist, but they are now part of larger provinces. 
The religious scene also changed. The country and its government are not "Christian" any more 22 . The public broadcaster is expected to reflect the religious plurality of the population. Even the educational system moved away from the vestiges of the "ChristianNational" ideology23. It isn't necessary for an individual to be a Christian in order to get a job. To the contrary, it may be helpful to belong to one of the earlier underprivileged groups.

In the eighties the term HIV-AIDS was unknown. Only specialists knew anything about it. Twenty years ago there was not even a rumbling of the distant storm. How the situation changed! KwaZuluNatal, traditionally one of the areas in South Africa with the highest growth rates, reported a negative growth rate in $1999 \ldots$ largely because of deaths due to AIDS (SA Survey 2000:218).

The nineteen nineties was the decade of talk about "post-modernism". In missiological circles this was brought about by the publication of the book by the late David Bosch: Transforming Mission. Paradigm Shifts in Theology of Mission (1991). The previous study of the missionary context didn't even once mention this term, even if the cities already manifested a kind of post-modern mentality. To what extent can the broader South African context already be described as being post-modern? What changes in the worldview of South Africans can already be observed?

Yes, this country and its people changed drastically. There is indeed an urgent necessity to give renewed attention to the context of the Church, and an urgent need to spell out the challenges of the new context to the Church in South Africa. This article endeavours to indicate some of the contours of such a study. But first a selective overview is given.

\subsection{Demographic Overview}

The following tables may give a rough picture of some demographical aspects of the country. Attention will only be given to (a) the growth of the population, where we will focus on the influx of foreigners and the emigration of others; and (b) the geographical distribution of the population, with particular attention to urbanisation and race. We want to

22 Both the preface to the (old) Constitution and the rhetoric of the (old) government created the perception that South Africa was a "civilised Christian nation". The other religions were there, and they enjoyed a measure of freedom of expression and worship, but nevertheless...

23 It seems as if religion is guaranteed a place in the schools of the future, but only in a more general sense of moral formation. 
know how many people there are, who they are, and where you could find them.

It may be worthwhile to compare the total population of $1980^{24}$ with that of the year 199925 . For the sake of clarity the main population groupings are retained.

Table 1: The South African population, $1980 \& 1999$ (in thousands) ${ }^{26}$

\begin{tabular}{|l|c|c|c|c|}
\hline Population Group & $\begin{array}{c}\mathbf{1 9 8 0} \\
\text { Number }\end{array}$ & $\begin{array}{c}\mathbf{1 9 8 0} \\
\%\end{array}$ & $\begin{array}{c}1999 \\
\text { Number }\end{array}$ & $\begin{array}{c}\mathbf{1 9 9 9} \\
\%\end{array}$ \\
\hline Blacks & 21403 & 73 & 33631 & 78 \\
\hline Whites & 4528 & 15 & 4539 & 11 \\
\hline Coloureds & 2613 & 9 & 3793 & 9 \\
\hline Asians & 821 & 3 & 1092 & 3 \\
\hline TOTAL & 29365 & 100 & 43054 & 100 \\
\hline
\end{tabular}

According to these figures, there has been a marked growth in the total population of some $47 \%$ during these two decades. It was, in any case, a higher growth rate than was expected. Information is available that could shed further light on the relative growth rates of the different population groups and geographical areas. But it is already clear that the growth rate among Blacks is higher. That is the reason why they comprise a growing percentage of the total population.

One of the explanations for the higher than expected population is the presence of an unknown number of (illegal) immigrants from (especially) other African countries. The estimations vary between 500 000 and 4,1 million (SA Survey 2000:23). Sometimes even higher figures are quoted, but without substantiation. Whatever the number may be - and it seems to be substantial - this reflects not only the sad state of affairs in these other countries, but also the liberal policies (at first) of the new South African government. However, this is not regarded in the same light on the ground, where people are resenting

24 This is based on Kritzinger 1985. One of the problems of the government census of 1980 was that it excluded the populations of the then Transkei, Bophuthatswana, Venda and Ciskei, the "independent" homelands. Kritzinger $(1985: 9,14)$ tried to provide totals which are more or less comparable. These figures were in any case officially revised from time to time, as the census procedures and calculations were refined.

25 These are the calculated mid-year 1999 figures, based on the 1996 census, published by Stats SA in a Statistical Newsletter of 12 July 1999.

26 The rounding of the figures in all the following tables result in the totals not always adding up correctly. 
the competition for jobs that these foreigners represent ${ }^{27}$. On the other hand, the church cannot but think of all the biblical injunctions regarding the "foreigner in your midst" 28 .

Another fact is that a tragic "brain drain" from the country is currently under way. Especially (but not exclusively) white professionals are leaving the country in their droves. Since 1994 there was a yearly net loss of people to emigration (SA Survey 2000:21), even while it is known that those who openly declare themselves to be emigrants is but a small percentage of those who are, for all practical purposes, leaving for good. In 1996 the Australian census counted 56 000 official South African immigrants, Canada had 14000 , New Zealand more than 20000 , and the UK close to 100000 (SA Survey 2000:24).

Table 2: The population of the different provinces of South Africa, 1999

\begin{tabular}{|l|l|l|l|}
\hline \multicolumn{4}{|l}{$\begin{array}{l}\text { Estimations for mid-year 1999, in thousands, } \\
\text { male and female, from largest to small }\end{array}$} \\
\hline \multirow{4}{*}{ KwaZulu-Natal } & $M$ & 4226 & \\
\hline & $F$ & 4699 & \\
\hline & Tot & 8925 & $21 \%$ \\
\hline \multirow{5}{*}{ Gauteng } & $\mathrm{M}$ & 3992 & \\
\cline { 2 - 5 } & $\mathrm{F}$ & 3815 & \\
\hline \multirow{5}{*}{ Eastern Cape } & Tot & 7807 & $18 \%$ \\
\hline \multirow{5}{*}{ Northern Province } & $\mathrm{M}$ & 3105 & \\
\hline & $\mathrm{F}$ & 3554 & \\
\hline & Tot & 6659 & $15 \%$ \\
\hline \multirow{4}{*}{ Western Cape } & $\mathrm{M}$ & 2472 & \\
\hline & $\mathrm{F}$ & 2865 & \\
\hline & Tot & 5337 & $12 \%$ \\
\hline & $\mathrm{M}$ & 2050 & \\
\hline & $\mathrm{F}$ & 2121 & \\
\hline & Tot & 4171 & $10 \%$ \\
\hline
\end{tabular}

27 There were already some ugly insidents where foreigners were mobbed by angry unemployed people.

28 To a certain extent, these people can all be called "economic refugees". They fled from situations where staying on is almost akin to suicide. Nevertheless, during 1998 a total of 181286 people were repatriated as illegal immigrants, $78 \%$ of them to Mozambique (SA Survey 2000:24). 


\begin{tabular}{|l|l|c|c|}
\hline \multirow{3}{*}{ North West } & $\mathrm{M}$ & 1760 & \\
\hline & $\mathrm{F}$ & 1802 & \\
\cline { 2 - 4 } & Tot & 3562 & $8 \%$ \\
\hline \multirow{3}{*}{ Fpumalanga } & $\mathrm{M}$ & 1469 & \\
\hline & $\mathrm{F}$ & 1534 & \\
\hline & Tot & 3003 & $7 \%$ \\
\hline \multirow{3}{*}{ Northern Cape } & $\mathrm{M}$ & 1310 & \\
\hline & $\mathrm{F}$ & 1405 & \\
\hline & Tot & 2715 & $6 \%$ \\
\hline \multirow{3}{*}{ TOTAL } & $\mathrm{M}$ & 432 & \\
\hline & $\mathrm{F}$ & 444 & \\
\hline & Tot & 875 & $2 \%$ \\
\hline & $\mathrm{M}$ & 20814 & $48 \%$ \\
\hline & $\mathrm{F}$ & 22240 & $52 \%$ \\
\hline & Tot & 43054 & $100 \%$ \\
\hline
\end{tabular}

More than one third of the population live in the two coastal provinces of KwaZulu-Natal and the Eastern Cape. Together with Gauteng they represent more than $50 \%$ of the population.

Blacks comprise $97 \%$ of the population in the Northern Province, $91 \%$ in Northwest and $89 \%$ in Mpumalanga, making out a low of $21 \%$ in the Western and $33 \%$ in the Northern Cape. The 2,1 million Coloured population of the Western Cape has a majority of $54 \%$, and in the Northern Cape they comprise $52 \%$, but are a small minority elsewhere. The majority of Whites live in Gauteng (38\%), and in the Western Cape (19\%). In KwaZulu-Natal the number of Indians are only substantial (some 800000 , or $9 \%$, more than three-quarters of the total Indian population) - from the tables in Froise 1999:2-6.

Some $53 \%$ of the population live in urban areas, which includes towns and built-up areas of all descriptions. Although that means that South Africa has become moderately urbanised, it should not be forgotten that more people than ever before live outside these cities and towns, the majority of them in traditional and underdeveloped deep rural areas. In the Northern Province $89 \%$ are rural, in Northwest and the Eastern Cape also close to two out of three people are rural. The other side of the picture is the $97 \%$ urban population of Gauteng, and the $89 \%$ of the Western Cape (Froise 1999:7).

Two other interesting and relevant statistics in this context are the age profiles, and the languages spoken. 
a $45 \%$ of the South African population are under the age of $20 \ldots$ a good $47 \%$ of the Blacks and only $29 \%$ of the Whites. On the other hand only $4 \%$ of Blacks are older than 65 , whereas $10 \%$ of Whites are that already old... and 19\% of all White women (SA Survey 2000:11). The two important conclusions from this are (a) the importance of the youth in terms of sheer numbers, and (b) the growing percentage of the aged that will have to be looked after... especially if the expected future effect of AIDS kicks in (more about this later.)

a Of the nine official languages spoken in the country, IsiZulu is the home language of more than 9 million people $(23 \%)$. IsiXhosa comes next, with 7 million ( $18 \%$ ), and Afrikaans third with 5,8 million speakers. English comes fifth (3,5 million), after Northern Sotho (Froise 1999: 12). Although English seems to becoming the lingua franca in the country, it is by no means spoken generally. There are other languages that are of great importance in the communication of the gospel.

In summary, one can say that South Africa is a middle order country, with a relatively fast growing population, overwhelmingly Black, having a number of ethnic groups, but with sizeable minority cultures more akin to those of Europe. The population is spread across the country's nine provinces, with a few city cores, but almost half the population is still living in rural areas.

\subsection{Some socio-economic realities}

\subsubsection{Where does South Africa fit in in economic terms?}

One way of giving a general description is to use the centre-periphery image. The economy is to a (too) large degree centred on the Gauteng province (with Johannesburg as the main centre), as well as on the urban centres of Cape Town, Durban-Pietermaritzburg, and to a lesser extent Port Elizabeth-Uitenhage, East Londen and Bloemfontein. This could be called the centre. The rest of the country is the periphery. A small percentage of the economic product originates on the farms and in smaller urban centres, especially if given in per capita (per person) format. But the fact is that this periphery has also an outer periphery: the traditional areas comprising the millions of people from the traditional homelands and those areas populated with the "redundant people" of the apartheid era. In the nineteen eighties the per capita economic strength of these three circles were in the order of 28:3:1 (Kritzinger 1987:6).

During the past decade the contribution of the primary economic sector declined to about $10 \%$ of the GDP (gross domestic product), i.e. 
mining, down to less than $7 \%$, and agriculture to scarcely $3 \%$. Even manufacturing (the secondary sector) is down to $20 \%$. The relative growth was found in the tertiary service (government $17 \%$, transport, catering and communications $30 \%$ ) and financial sectors $(18 \%)$. The country therefore has a modern economy, but a relatively small one. It is a combination of a first world and third world economy. In terms of infrastructure and economic product it leads the African countries, but compared to the "developed" countries it falls far short in terms of per capita product.

There has been scarcely any growth in the economy over the past years. The $0,5 \%$ growth in GDP (gross domestic product) during 1998 was more than offset by the growth in population. The resulting real GDP (1998) per head was $-1,6 \%$, which represents a significant slide. The country is, at this stage, getting poorer (Fast Facts, Feb. 2000:14). In 1998 the real GDP per head was at a similar level to what it had been in 1970. The same happened with real disposable income per head. In 1998 it was 7\% below the peak of 1980 (SA Survey 2000:405). No wonder the confidence indicators stood around 25 on a scale of 0 to 100 (Fast Facts, Feb. 2000:13).

\subsubsection{Poverty is endemic to the country}

It is generally agreed that the eradication of poverty should be the priority task for the government and all economic role players in the country. More specifically, the question of employment is central. In a recent (February 2000) poll the HSRC found that a majority of the populàtion now rate this as a higher priority than the fight against crime (to which we will return).

Poverty has many faces (to refer to the book of Wilson and Ramphele which described poverty in South Africa, 198929). There are so many indicators of poverty. One can use the parable of the judgement (Mt 25) as structure: hungry, thirsty, homeless, naked, unwell, imprisoned... One measure of this is the so-called HDI (human development index), which measures on a scale of 0 to 1 , life expectancy, living standards and educational attainments. Here South Africa's mark is something like 0,677, comparable to Paraguay and Sri Lanka. Gauteng and Western Cape, however, had a high level of HDI, in the order of Singapore and Venezuela; the Northern Province was low, comparable to Zimbabwe; and the others were in the middle regions, comparable to China and Swaziland (SA Survey 2000:411-412).

29 It was found that a majority of the South African population lived under the bread line, a measure taking the cost of the most basic needs of a family into account (Wilson and Ramphele 1989:17). 
Unemployment ${ }^{30}$ is rife. The following table (from $S A$ Survey $2000: 305 / 7)$ is based on the figures of Stats SA.

Table 3: Unemployment rate for urban and non-urban areas, 1997 (in percentages)

\begin{tabular}{|l|c|c|c|c|c|}
\hline & African & Coloured & Indian & White & TOTAL \\
\hline Urban & 42,9 & 24,5 & 13,4 & 6,6 & 32,6 \\
\hline Non-urban & 53,0 & 13,0 & 16,1 & 8,5 & 49,5 \\
\hline TOTAL & 46,8 & 23,0 & 13,5 & 6,7 & 37,6 \\
\hline
\end{tabular}

This is not a pretty picture, but the bad news is that it gets worse. Only a small percentage of new entrants to the labour market can hope to find a job. From 1980 to 1994 only 142000 new opportunities were created, but the labour force increased by several millions. By 1999 the decrease in non-agricultural employment was a further 7\% from 1994 (especially in the mines: $30 \%$, and construction: $38 \%$ ) - Fast Facts, Feb. 2000:13. Many of the workers end up in the informal sector (some 1,8 million), which account for about $7 \%$ of the gross domestic product (SA Survey 2000:270), but can't make up for all the other job losses.

\subsubsection{Poverty and wealth}

South Africa is not only in a less than ideal situation in terms of poverty, absolute poverty, but also in terms of relative poverty. The unemployed, and certain categories of workers are indeed poor (in 1996 at least $60 \%$ of all workers received monthly incomes of less than R1 500 ). But others receive exhorbitant salaries (some $2 \%$ received more than R1 l 000) - SA Survey 2000:293. However, the real rich were not in the category of "employed". They were the "capitalists", who employed others, or simply "made money" through their share in capital.

In the past, the income gap was highly correlated with the racial divide. That has changed to a large extent over the past years. Not only have the wages increased sharply for the lower income groups, but a programme of affirmative action put relatively more Blacks into jobs as such, but higher paying jobs in particular. Something of this trend can be seen in the following table.

30 There are different definitions of unemployment. I here use the "expanded definition", which counts those in the economic active years, who (a) were not employed on the previous 7 days, and (b) want to work, and are ready to start working within the following 7 days. The "strict" definition adds the following: "have taken active steps to find work during the previous 4 weeks" (SA Survey 2000:300). 
Table 4: Proportion of households in each income quintile by race in the 12 main urban centres, in 1990 and 1995 (from richer to poorer) (SA Survey 2000:297)

\begin{tabular}{|l|c|c|c|c|c|}
\hline & Quintile 1 & Quintile 2 & Quintile 3 & Quintile 4 & Quintile 5 \\
\hline African & & & & & \\
1990 & $2 \%$ & $10 \%$ & $23 \%$ & $31 \%$ & $34 \%$ \\
1995 & $6 \%$ & $9 \%$ & $18 \%$ & $29 \%$ & $38 \%$ \\
\hline Coloured & & & & & \\
1990 & $8 \%$ & $28 \%$ & $33 \%$ & $20 \%$ & $12 \%$ \\
1995 & $9 \%$ & $26 \%$ & $17 \%$ & $35 \%$ & $13 \%$ \\
\hline Indian & & & & & \\
1990 & $17 \%$ & $35 \%$ & $27 \%$ & $12 \%$ & $8 \%$ \\
1995 & $27 \%$ & $22 \%$ & $25 \%$ & $12 \%$ & $15 \%$ \\
\hline White & & & & & \\
1990 & $51 \%$ & $30 \%$ & $12 \%$ & $5 \%$ & $3 \%$ \\
1995 & $33 \%$ & $29 \%$ & $22 \%$ & $10 \%$ & $6 \%$ \\
\hline
\end{tabular}

What is notable is that, whereas increasing numbers of Blacks, Coloureds and especially Indians moved into the top quintile, the Whites among the top earners decreased dramatically. This trend is definitely continued - and at a pace - after 1995.

It should nevertheless be noted that the income gap, to a large extent, still corresponds with race. If one compares the Black and White incomes it is still glaring that only $6 \%$ of the Blacks were in the top group in 1995 , compared to the $33 \%$ of the Whites. And, while only $6 \%$ of the Whites languished in the bottom quintile, not less than $38 \%$ of the Blacks were there.

From facts like these follows the important political focus on the eradication of any remaining privileges for the previously privileged group. The liberation is not yet fully attained, it is said. The overturning of the most important tables - the economic liberation - still lies in the future. The arena of the present and future struggle is not politics any more, but economics.

\subsubsection{Education}

South Africa, traditionally, had a separated educational system. The different racial groups had separate (but not equal!) educational structures. That of the White population was far better funded and run, and produced high quality results. Black education, on the other hand, also had to deal with the heritage of the 1976 Soweto uprising of the youth that disturbed the normal functioning of schools for a generation. Integrating these various traditions into a single system is a daunting task. 
Several problems need to be solved at this stage. While the erstwhile white schools suffer a definite fall in standards, because of the larger classes and the influx of large numbers of learners without a solid background, it is not as if the former black schools are progressing. It sometimes seems as if the whole system is pulled down to the lowest common denominator.

Illiteracy is far from being stamped out in South Africa. If an illiterate is defined as someone with none or less than 7 years of schooling, there are 7,6 million, or $36 \%$ of those older than 20 who are illiterate (SA Survey 2000:112). This differs much between the provincial areas, from the $49 \%$ in the Northern Province to the $21 \%$ in Gauteng. Almost a quarter of adult Africans had no schooling, compared with $10 \%$ for Coloureds, $7 \%$ for Indians, and 1\% for Whites.

\subsubsection{Health and welfare}

The distribution of medical and welfare services is very skewed. The church should take up the plight of the poorest of the poor, who are often left out. The government is trying - against odds - to provide free primary health care and affordable medical services for the whole population, without any discrimination. However, the available resources are making this impossible. Equal access for all people to medical services is taken a step further in the recent law governing medical aid funds. Administrative and ideological blunders, however, are sabotaging the whole process of providing adequate medical care for all. Medical costs were expected to rise by $20 \%$ in 1999 (SA Survey 2000:226).

The most frightening current phenomenon is the growing presence of HIV-AIDS.

Some of the figures quoted in the press over the past year are disturbing:

* Some 5,6 million people in South Africa will be HIV positive by $2005 \ldots$ more than $18 \%$ of the workforce.

* Almost 250000 people will die annually because of AIDS in the next three years, increasing to 500000 by 2007 . By 2008 the cumulative total will be 4 million.

* By 2010 the life expectancy of South Africans will fall to 48 years from the current 68 , i.e. by some $30 \%$. The population growth rate will drop from $1,4 \%$ to $0,4 \%$ (SA Survey 2000:218).

An issue of great moral impact was the recent legalisation of abortion. It was reported that during 1998 some 46000 "safe abortions" were performed in the country. Despite opposition by religious groups the Transvaal High Court ruled that the abortion laws did not violate the 
constitutional guarantee of the right to life (SA Survey 2000:508). This was especially ironic in the light of the parallel strong opposition from government to the re-institution of the death penalty, because of a person's right to life!

\subsubsection{Social life}

The high levels of crime are reducing the quality of life for millions of South Africans. While the discussions usually centre on the stronger measures that should be taken by government to curb the crime and violence, it is clear that these are symptoms of a deeper malady in the social fabric of society. The church - and all religious and social structures - should be deeply challenged by figures like the following:

* One in every six men and one in every eight women were the victims of at least one individual crime in $1997 \ldots 3,8$ million people.

* $21 \%$ of all households experienced at least one crime during 1997.

Table 5: National crime trends (Fast Facts, Feb. 2000:12)

\begin{tabular}{|l|c|c|}
\hline Crime & $\begin{array}{c}\text { Number per 100 } \\
000 \text { of population } \\
\text { Jan - Oct 1999 }\end{array}$ & $\begin{array}{c}\text { Change on 5 } \\
\text { years ago }\end{array}$ \\
\hline Violent crime & 45 & $-21 \%$ \\
Murder & 54 & $-7 \%$ \\
Attempted murder & 185 & $+2 \%$ \\
Robbery with aggravated circ. & 95 & $+10 \%$ \\
Rape & 464 & $+8 \%$ \\
Assault with grievous intent & 407 & $+2 \%$ \\
Common assault & & $+13 \%$ \\
\hline Property crime & 548 & $-7 \%$ \\
Burglary (residential) & 180 & $+96 \%$ \\
Burglary (business) & 134 & $-11 \%$ \\
Other robbery & 202 & $-5 \%$ \\
Vehicle theft & 375 & $+12 \%$ \\
\hline Theft from vehicle & 913 & $-7 \%$ \\
\hline Other thefts & 126 & $+3 \%$ \\
\hline Commercial crime & 4362 & \\
Fraud, embezzlement, etc. & & \\
\hline Twenty serious crimes & & \\
\hline
\end{tabular}

It is indeed thought provoking that affluent households experienced fewer crimes than poor households!

All this boils down to serious problems in the backbone of society: the household. The previous political system of migrant labour, influx control, single sex hostels, rented "match box" houses, popu- 
lation removals, etc. played a large role in breaking down the Black family. Other factors of modernity and secularisation probably also did a lot of harm in other communities. But things changed. What are the factors which should be addressed today? That should be determined. Two important factors related to the health of the house-hold are housing and income.

In 1996 the official figure of the housing shortage for the 9,1 million households was 2,6 million urban homes (excluding the traditional - mostly rural - structures). Of the 6,5 million African dwellings $41 \%$ were formal (brick) structures, $25 \%$ traditional, and $21 \%$ informal shacks (SA Survey 2000:164). Most of these do not really make a healthy family life possible. They do not even always afford shelter against the elements: cold in winter, hot in summer, wet when it rains, and dangerously fire prone.

We already quoted figures showing the extent of unemployment. It is worst among the Black population (47\% in 1997) - SA Survey 2000:304, but affects many households in all population groups. But even those who do work, often bring back so little wages that permanent poverty is the only future for the family, for example: $50 \%$ of the African households had an income of less than Rl 000 per month in 1998 (SA Survey 2000:296).

\subsubsection{The environment}

This most important aspect is often left out when the challenges for mission are enumerated. However, such an oversight reveals not only an unsatisfactory understanding of mission, but also a superficial grappling with the context.

God is not only interested in the wellbeing of humankind. One may even say that $\mathrm{He}$ is primarily interested in (the whole of) his creation. Humanity, created "in his image", has a central role to play: to represent God in the affairs of creation, to enable all of creation to honour the Creator. That is why the condition of the environment concerns the church. The church can only address human beings. So, especially when the health of the environment is threatened by human folly, the task is the proclamation of the reign of God. "Repent, for the kingdom of God is near!" The task is prophetic, but also pastoral.

The environment is indeed under threat, not only worldwide, but also in South Africa. However, much of the ecological crisis is intertwined with the wellbeing also of people... and especially the poor. 
The church is confronted with a combination of "green" and "brown" issues ${ }^{31}$.

\subsection{Aspects of the religious scene}

On the religious statistics Professor Jurgens Hendriks has published an intensive analysis of the 1996 census as a chapter in the book of Marjorie Froise (1999:48). My own calculations, based on unpublished information obtained from Stats SA, and extrapolated to mid-year 1999, are contained in the following table.

Table 6: The religious affiliation of the South African population, mid-year 1999, based on the 1996 census

\begin{tabular}{|l|c|c|}
\hline RELIGIOUS DENOMINATION & $\begin{array}{c}\text { MEMBERS IN } \\
\text { THOUSANDS }\end{array}$ & $\begin{array}{c}\text { PERCENTAGE } \\
\text { OF POPULATION }\end{array}$ \\
\hline Zion Christian Churches & 4181 & 9,71 \\
NG Church family & 3810 & 8,85 \\
Catholic Churches & 3703 & 8,60 \\
Methodist Churches & 3035 & 7,05 \\
Pentecost/Charismatic Churches & 2381 & 5,53 \\
Anglican Churches & 1731 & 4,02 \\
Apostolic Faith Mission & 1214 & 2,82 \\
Lutheran Churches & 1137 & 2,64 \\
Presbyterian Churches & 788 & 1,83 \\
Ibandla LamaNazaretha & 491 & 1,14 \\
Baptist Churches & 474 & 1,10 \\
Congregational Churches & 465 & 1,08 \\
Orthodox Churches & 34 & 0,08 \\
Other Apostolic Churches & 3802 & 8,83 \\
Other Zionists & 2334 & 5,42 \\
Ethiopian type Churches & 865 & 2,01 \\
Other Reformed Churches & 418 & 0,97 \\
Other African Indep. Churches & 250 & 0,58 \\
Other Christian Churches & 1365 & 3,17 \\
\hline SUBTOTAL:CHRISTIAN & 32502 & 75,49 \\
CHURCHES & & \\
\hline
\end{tabular}

31 The real challenge is not to give attention to either the green issues - of pollution and over exploitation - or the brown issues - of poverty and injustice - but to their interrelation in the context of a wider concern for God's wonderful creation. Humanity is but a part, be it an important part, of creation. We are made from the dust of the earth. 


\begin{tabular}{|l|c|c|}
\hline Muslim Faith & 598 & 1,39 \\
Hindu Faith & 581 & 1,35 \\
Judaists & 73 & 0,17 \\
African Traditional Belief & 17 & 0,04 \\
Other faiths & 207 & 0,48 \\
\hline SUBTOTAL: & 1481 & \\
OTHER RELIGIONS & 5016 & 3,44 \\
\hline No religion & 4051 & 11,65 \\
Refused, other, not stated & & 9,41 \\
\hline SUBTOTAL: & 9072 & 21,07 \\
\hline UNCERTAIN RELIGION & 43054 & 100,00 \\
\hline TOTAL POPULATION & & \\
\hline
\end{tabular}

Some of the main facets of this (statistical) religious picture are:

* Christianity is nominally the religion of 3 out of 4 South Africans;

* The other religions are statistically almost negligible on their own;

* About 1 in 5 are not sure about the question, or have reasons not to identify themselves as adherents of any religion. Most of these are probably traditionalists... as are many of those Blacks who have given their affiliation as Christian 32 .

* Not only is the group of Independent Churches by far the largest religious group (about 28\%), but the ZCC is the single largest church/ denomination.

* The Pentecostal-Charismatic-Evangelical group of churches are growing to such an extent that they may already be larger than the Dutch Reformed Church family.

Despite the relative small number of Muslims, Hindus and Jewish believers (not to speak of others) the present emphasis on human (and religious) rights causes them to have an equal say with the Christians in religious matters. The government is officially secular (neutral) and is seeing to it that no religion is accorded more rights than others. These smaller religions, therefore, have more opportunities than before to propagate their beliefs. The greater visibility given to these other religions also leads to a greater awareness of each other, and conscious efforts to greater understanding and cooperation in society. There is a

32 This is not only a subject for a good debate, but also demands much closer research. 
strong movement of interreligious relations and dialogue. All this seems to lead to a religious relativism at times. The situation represents a great challenge to the churches ${ }^{33}$.

As already mentioned, the basic philosophy (or ideology) of the present time is the upholding of the rights of the individual person. The church certainly has the obligation to critically accompany these developments. Elements of the general mentality of the present time lead to liberal views in moral issues and the dangerous erosion of values in all sections of the community. This certainly presents the Christian church - as it does other institutions - with a critical challenge.

\section{A NEW ENQUIRY}

What is written above serves to introduce an enquiry, recently launched by a group of mission academics and practitioners, calling themselves the Missions Research Network (Missnet). With the blessing of the two major Christian networks - the South African Council of Churches (SACC) and The Evangelical Alliance of South Africa (TEASA) - and the cooperation of a growing number of churches and mission organisations the research project Mission in the New South Africa (MINSA) was commenced in 1999. The process is planned to be as inclusive as possible: in terms of the vision of the church and its mission, the scope of the research, but also in terms of its partners. The dream is of a process taking a broad spectrum of the church into the future and challenging the whole church to be obedient to all that the church is called by her Lord to do in the world.

The plan involves geographical case studies on the one hand. Representative samples from the different kind of communities in the country (ranging from villages and tribes in the deep rural areas to the subcultures of the urban centres) have to be studied with the goal of understanding the needs and hopes of such people. Local people from these contexts have to be heard. The research should compose a picture that communicates the truth about the country in its different contexts.

But another dimension of the research will be the informed study of serious issues on a national level. Above we have mentioned such issues: poverty, unemployment, economic policies, AIDS, crime, and so forth. These type of issues are foremost in the experience of South Africans. What are the churches' views on these issues? What do the churches propose? What steps can be taken? The study should awaken

33 Theologically and missiologically speaking this is a difficult area to understand and formulate. The traditional ways of dealing with these questions are not always adequate. 
the church to, and inform the church of these issues, in order that more faithful steps could be taken by the various Christian communities to become involved - in the Lord's name - with the people and environment in need.

\section{Consulted literature}

Bosch, D J 1980. Witness to the World. The Christian Mission in Theological Perspective. Atlanta: John Knox Press.

Bosch, D J 1983. The Structure of Mission: an exposition of Matthew 28:16-20, in Wilbert R Shenk (ed), Exploring Church Growth. Grand Rapids: Eerdmans, 218-248.

Bosch, D J 1991. Transforming Mission. Paradigm Shifts in Theology of Mission. Maryknoll, NY: Orbis Books.

Fast Facts. Monthly bulletin of the South African Institute of Race Relations, February 2000.

Froise, M 1999. South African Christian Handbook 1999/2000. Welkom: Christian Info.

Gensichen, H-W 1971. Glaube für die Welt. Theologische Aspekte der Mission. Gütersloh: Gütersloher Verlagshaus Gerd Mohn.

Hendriks, H J 1999. Religion in South Africa: Census '96, in Froise (ed.), South African Christian Handbook 1999/2000, 49-91.

Kritzinger, J J 1985. Statistiese Beskrywing van die Godsdienstige Verspreiding van die Bevolking van Suid-Afrika. Pretoria: ISWEN.

Kritzinger, J J 1987. Die Onvoltooide Sendingtaak in die PWV-gebied. Deel 2: Die Arbeids-wêreld. Pretoria: ISWEN.

Kritzinger, J J 1988. The South African Context for Mission. Cape Town: Lux Verbi.

McGavran, D (ed) 1972. Crucial Issues in Missions Tomorrow. Chicago: Moody Press.

Neill, S 1959. Creative Tension. London: Edinburgh House Press.

Rainer, T S 1993. The Book of Church Growth. History, Theology, and Principles. Nashville: Broadman Press.

Randall, P 1973. A Taste of Power. The final, co-ordinated Spro-cas report. Johannesburg: SPRO-CAS.

2000. South Africa Survey 1999/2000. Johannesburg: SAIRR.

Surplus People Project 1983. Forced Removals in South Africa. 5 volumes. Johannesburg: SPP.

Wilson, F \& Ramphele, M 1989. Uprooting Poverty. The South African Challenge. Cape Town: David Philip. 